Article

\title{
Corporate Responsibility for Human Rights in Assam Tea Plantations: A Business and Human Rights Approach
}

\author{
Madhura Rao ${ }^{1}$ (D) and Nadia Bernaz ${ }^{2, *(D)}$ \\ 1 Food Claims Centre Venlo, Maastricht University, 5911 BV Venlo, The Netherlands; \\ m.rao@maastrichtuniversity.nl \\ 2 Law Group, Wageningen University, 6708 PB Wageningen, The Netherlands \\ * Correspondence: nadia.bernaz@wur.nl
}

Received: 16 July 2020; Accepted: 7 September 2020; Published: 9 September 2020

check for updates

\begin{abstract}
This paper explores how UK-based companies deal with their responsibility to respect the human rights of Assam (India) tea plantation workers. Through qualitative content analysis of publicly available corporate reports and other documents, it investigates how companies approach and communicate their potential human rights impacts. It highlights the gap between well-documented human rights issues on the ground and corporate reports on these issues. It aims to answer the following research question: in a context where the existence of human rights violations at the end of the supply chain is well-documented, how do companies reconcile their possible connection with those violations and the corporate responsibility to respect human rights under the United Nations Guiding Principles on Business and Human Rights? This paper reveals the weakness of the current corporate social responsibility (CSR) approach from the perspective of rights-holders. It supports a business and human rights approach, one that places the protection of human rights at its core.
\end{abstract}

Keywords: tea plantations; Assam; business and human rights; corporate social responsibility; UN Guiding Principles on Business and Human Rights; UK Modern Slavery Act

\section{Introduction}

This paper explores how UK-based tea companies deal with their responsibility to respect the human rights of Assam tea plantation workers. Under the United Nations Guiding Principles on Business and Human Rights (Guiding Principles, or UNGPs), all companies, irrespective of size and location, should respect human rights. As explained in Guiding Principle 11, "this means that they should avoid infringing on the human rights of others and should address adverse human rights impacts with which they are involved" [1]. Guiding Principle 21 further demands that companies communicate on how they address their human rights impact by providing "information that is sufficient to evaluate the adequacy of an enterprise's response to the particular human rights impact involved" [1]. Using publicly available corporate reports and other documents, this paper investigates how these companies approach and communicate their potential human rights impacts in Assam. It highlights the gap between, on the one hand, complex and well-documented human rights issues on the ground and, on the other hand, corporate reports on these issues.

Tea is the second most consumed beverage in the world, subsequent only to water. Globally, India is the second largest producer of tea [2], and the Indian state of Assam is the world's largest tea growing region [3]. The history of tea in India dates to the late 1830s when British explorers discovered tea bushes in the lowlands of Assam. Driven by the necessity to find an alternative to Chinese imports, tea production in British India received immense encouragement [4]. Estimated to be employing 
around 3.5 million workers at present, the tea industry is India's largest private sector employer [5]. Most of the tea plantation workers in Assam are Adivasis, indigenous people who are descendants of displaced workers from neighbouring states. Colonial tea planters forcefully relocated them to the region [6]. It has been 73 years since India's independence, but the tea plantation workers in Assam are not far ahead of their ancestors when it comes to their human rights. Following a fact-finding mission, the Global Network for the Right to Food and Nutrition [3] reported that as of May 2016, tea workers in Assam are largely dependent on plantation owners for their sustenance and basic needs such as food, water, and housing [3]. The report also highlights that despite having lived in the same estate for over 200 years, workers have no right to their homestead and can be evicted at the whim of the management. A high mortality rate and low wages coupled with a lack of alternative employment opportunities have resulted in these workers falling into a vicious circle of poverty and deprivation [3].

A lack of transparency in the global tea supply chain makes it difficult to trace the origin of blended tea sold in western markets. It is a known fact that major tea brands such as Tata Global Beverages, PG tips, Tetley, and Twinings source their tea from parts of India, including Assam, but which gardens produce tea for which company is unclear [7]. This, as well as the obstacles that stand in the way of legal remedies in transnational business and human rights (BHR) litigation, make it unlikely to ever see a European-based tea company being held liable in its home country for its human rights impacts in Assam [8-10]. Corporate transparency legislation makes it possible, however, that corporations themselves draw attention to their links with Assam tea plantations through non-financial reporting [11]. As shown below, some do.

A growing body of academic literature looks at how companies report on non-financial issues, including human rights. Studies have focused on certain countries [12] (p. 29), and issues, for example modern slavery [13-15]. They highlighted how those reports engage superficially with human rights issues, following instead a "managerial logic" [16], whereby professionals attempt to map the company's potential human rights impact and devise processes to manage them. The mapping exercise is difficult, especially when the company's supply chains are complex. Corporate reporting on human rights issues and the literature attempting to explain it tend to follow a top-down approach. The starting point is how the company addresses an external problem. By contrast, this paper focuses on abuse in one specific region, and looks at how companies manage evidence of such abuse. Assam tea is a good case study because the human rights violations in Assam tea plantations are well-documented, and the tea supply chain is relatively simple, with the product undergoing little transformation between the fields and the consumer's teacup. Our approach is bottom-up, and the focus is on rights-holders. The starting point is a description and legal characterization of the working and living conditions of tea plantation workers. Overall, the article aims to answer the following research question: in a context where the existence of human rights violations at the end of the supply chain is well-documented, how do companies reconcile their possible connection with those violations and the corporate responsibility to respect human rights under the UN Guiding Principles on Business and Human Rights?

The next section presents the relevant business and human rights framework for this study and a literature review on the living and working conditions of Assam tea workers. Section 3 describes the methods and material used. Section 4 is the empirical part. It analyses publicly available information about UK top tea businesses and their connection with Assam plantations, including what companies themselves have published about Assam. Section 5 discusses our findings and answers the research question. In the concluding remarks, we reflect on the limitations of the study and make recommendations for further research on the topic. Ultimately, the paper reveals the weakness of the current approach, characterized as a corporate social responsibility (CSR) approach from the perspective of rights-holders. It makes the case for a BHR approach, which places the protection of human rights at its core. 


\section{Literature Review}

\subsection{Business and Human Rights Context}

As noted above, companies have a responsibility to respect human rights under the 2011 UN Guiding Principles on Business and Human Rights. To meet this responsibility, they should, inter alia, set up a robust "human rights due diligence process to identify, prevent, mitigate and account for how they address their impacts on human rights" [1]. Guiding Principle 21 demands that companies communicate how they address their human rights impacts in an adequate form and frequency, and in a way that allows assessing the adequacy of their response. In this article, we explore how companies reconcile their responsibility to respect human rights with human rights violations on the ground. As such, we contribute to a better understanding of how the UNGPs are implemented in practice. The study of the Guiding Principles' implementation, limitations and impact falls within the field of business and human rights (BHR). BHR scholarship remains primarily located in the legal discipline. BHR is a field of study "about how business may negatively impact human rights and the various ways in which such violations can be prevented and addressed, including how business can be held accountable" [17] (p. 3). Since the adoption of the UNGPs, numerous studies have focused on their impact and limitations [18-21], and on the current plans to develop a BHR treaty to ground the UNGPs in international law [22-25]. BHR also includes an emerging research agenda in management, particularly in the sub-field of social issues in management (SIM) [26,27]. In this section, we highlight two important gaps in the existing literature on business and human rights.

First, no study has focused on the implementation of the UNGPs in the food sector. Legal articles have unpacked the implications of the responsibility to respect human rights in different sectors. We note, for example, studies focusing on military and security companies [28]; extractives [29]; oil and gas [30]; banking [31], mutual funds [32]; pharmaceuticals [33] and agribusiness [34,35]. However, so far, no academic study has used the responsibility to respect human rights under the UNGPs as a lens through which to analyse human rights issues in food supply chains. Our article, with its narrow focus on a selection of fast-moving consumer goods companies that sell tea directly to consumers, and on human rights issues in Assam tea plantations, is a first contribution in this direction. As such, we fill a gap in the existing BHR legal literature.

Second, the existing literature on corporate reporting as a tool to enhance accountability for human rights does not generally link existing, specific human rights abuses with reporting practices. Past studies have, for example, looked at the prevalence of reporting, and the reasons for reporting $[36,37]$. In this literature, human rights remains a largely theoretical concept, just like corporate reports themselves engage superficially with human rights issues even in the case of mandatory reporting [13]. Our study contributes to this literature by adopting a different perspective. The starting point is an account of human rights abuses in Assam. Those abuses are well-documented, widespread, serious, and violate numerous international legal standards. Companies that source from Assam are connected with those abuses, whether or not they choose to disclose their connections. These connections are necessarily close because tea supply chains are relatively simple and short compared to those of other products. This set of circumstances allows us to take a fresh look at reporting, and to ask a novel research question: in a context where the existence of human rights violations at the end of the supply chain is well-documented, how do companies reconcile their possible connection with those violations and the corporate responsibility to respect human rights under the UN Guiding Principles on Business and Human Rights?

\subsection{Living and Working Conditions of Assam Tea Workers}

In 1948, India was among the 48 members of the United Nations who voted in favour of the Universal Declaration of Human Rights. Since its independence, India has ratified several international human rights treaties that are of relevance to the Assam tea plantation workers, specifically the International Covenant on Economic, Social and Cultural Rights (ICESCR), the Convention on the 
Elimination of All Forms of Discrimination Against Women (CEDAW) and the Convention on the Rights of the Child (CRC). At the domestic level, the Protection of Human Rights Act (1993) is an important piece of legislation, but it is the 1951 Plantation Labour Act (PLA) which forms the legal backbone of the tea industry. The PLA seeks to ensure fair treatment and socio-economic security for the plantation workers. Yet, workers continue to be exploited because implementation is not systematic. Finally, as mentioned in the introduction, under the 2011 UN Guiding Principles on Business and Human Rights, all companies have the responsibility to respect human rights. As per Guiding Principle 13 , they should "(a) avoid causing or contributing to adverse human rights impacts through their own activities, and address such impacts when they occur" and "(b) seek to prevent or mitigate adverse human rights impacts that are directly linked to their operations, products or services by their business relationships, even if they have not contributed to those impacts" [1]. Under the Guiding Principles, "human rights" are to be understood "at a minimum" as the Universal Declaration of Human Rights, the International Covenant on Civil and Political Rights, the International Covenant on Economic, Social and Cultural Rights and the International Labour Organization's Declaration on Fundamental Principles and Rights at Work [1].

In June 2018, we conducted a literature search using 'Assam', 'tea', and 'human rights' as key words to identify pertinent literature published between 2013 and 2018. The time frame was restricted so as to be able to draw a fair comparison with the selected companies' modern slavery reports, which were first published in 2016. Most journal articles that were assessed as part of the literature search focused on specific tea estates or regions within Assam. These articles were not included because they did not provide a comprehensive overview of the topic. Investigative reports, on the other hand, were more exhaustive in their approach and reported findings from field work that spanned several months and often involved more informants. Our selection criteria included (i) transparency regarding funding, institutions involved, and motivation behind undertaking the study, (ii) inclusion of multiple tea estates, (iii) soundness of research design, and (iv) the use of primary data collected via field visits and interviews with relevant actors, including plantation workers. The following three reports were selected based on these criteria (see also a summary in the Supplementary Materials):

a. Report titled 'The More Things Change ... ', by the Human Rights Institute, Columbia Law School, published in 2014 [5].

This report focuses on the Amalgamated Plantations Private Ltd. (APPL) (Kolkata, India), which is the second largest producer of tea in India. This focus is due to APPL's position as a powerful private company with an expansive rhetoric and reputation of social accountability and its decision to infuse its investment with public actors by partnering with the World Bank. Based on scoping research and preliminary visits, the research team identified and visited 15 plantations in Assam and its neighbouring state, West Bengal, in 2012 and 2013. This report offers relevant insights for this paper in the form of non-participant observations about accommodation and sanitary infrastructure as well as working conditions. This report will be referred to as the Columbia report hereafter.

b. Report titled 'A life without dignity—-the price of your cup of tea', by the Global Network for the Right to Food and Nutrition, published in 2016 [3].

The aim of this study was to verify previously reported instances of human rights violations on tea plantations in Assam and West Bengal. The involved researchers visited 17 plantations, interviewed approximately 300 workers, and met with relevant actors, including representatives from local groups supporting workers, academia, trade unions, tea plantation companies, and local, state and central government. Data were gathered by means of structured and semi-structured interviews conducted in local languages, with help from interpreters with extensive knowledge about the tea sector. The field research was conducted in 2015 and 2016. This report will be referred to as the GNRTFN report hereafter.

c. Report titled 'The Global Business of Forced Labour-Report of Findings', by the Sheffield Political Economy Research Institute, University of Sheffield, published in 2018 [38]. 
With a focus on investigating the business models of forced labour in global agricultural supply chains, this report sheds light on labour rights in the cocoa industry in Ghana and the tea industry in India. The project combined multiple qualitative methods-including supply chain mapping, ethnographic research, and interviews-with a mixed quantitative-qualitative survey. For the section on the Indian tea industry, plantations from the states of Assam and Kerala were considered. Conclusions were based on surveys ( $N=563$ ), interviews $(N=61)$, and visits to six plantations in Assam. Our literature review only reflects observations from Assam. This report will be referred to as the Sheffield report hereafter.

For certain subsections, other reports and publications were used for supporting the findings of these three reports. We characterize the situation in Assam as human rights violations under international law, and as violations of the 1951 Plantation Labour Act (PLA); thus, providing the background necessary to answer the research question.

\subsubsection{Housing}

Evidence from all three reports indicates that accommodation provided to the workers was in a dilapidated condition. In interviews conducted for the GNRTFN [3] and Columbia reports [5], workers criticised the management for the poor conditions of their living quarters, which were built 50 to 60 years ago. Labour lines in public view were reported to be cleaned up by the management only when an inspection was due. Leaking roofs and a lack of a sufficient number of houses were identified as key issues by the GNRTFN [3] and Columbia reports [5]. Section 15 of the PLA states that it is the duty of the plantation owners to provide and maintain necessary housing accommodation for every worker and their family. Thus, the conditions described in the reports appear to be in violation of the PLA. Moreover, Article 11(1) of the ICESCR reads as follows: "The States Parties to the present Covenant recognize the right of everyone to an adequate standard of living for himself and his family, including adequate food, clothing and housing, and to the continuous improvement of living conditions". The UN Committee on Economic Social and Cultural Rights, the body in charge of monitoring the implementation of the Covenant by states parties further elaborated on the contours of the right to adequate housing in its 1991 General Comment No 4, which provides that "the right to housing should not be interpreted in a narrow or restrictive sense which equates it with, for example, the shelter provided by merely having a roof over one's head or views shelter exclusively as a commodity. Rather it should be seen as the right to live somewhere in security, peace and dignity".

Thus, although management was reported to be providing some accommodation to tea plantation workers, the workers' rights may still be violated. Using the GNRTFN report [3] as its source, the UN Special Rapporteur on the Right to Adequate Housing noted in their report following their country visit to India that the "housing and living conditions" of the Assam tea plantation workers, "and the insecurity of tenure that they endure, are cause for concern". (para. 69).

\subsubsection{Sanitation and Water}

Like the housing, the current latrines on most plantations were documented to be nearly 50 years old and in a state of dysfunction [3]. Unmanaged sewage on the labour lines was reported to be a major problem, with refuse flowing directly into the yards of inhabitants [5]. Open cesspools, raw sewage from latrines, and clogged shallow ditches were a common sight in the labour lines [5]. Field observations from the GNRTFN and Columbia report indicated that due to improper management of sewage, water often gets contaminated with human refuse $[3,5]$. The workers used to be able to clean the water using disinfectant provided by the management [3]. However, the management stopped providing disinfectant and the workers cannot afford to purchase it anymore [3]. Consumption of untreated ground water is the primary cause of water-borne diseases such as diarrhoea and cholera, which are prevalent among the plantation workers [3,5].

Section 8 of the PLA requires the employer to provide and maintain a sufficient supply of clean drinking water for all workers. Section 9 directs plantation owners to provide a sufficient number of accessible and well-maintained latrines and urinals on plantations. The non-provision of water 
and good sanitation is therefore a violation of the PLA and a breach of the human right to water, as articulated by the Committee on Economic, Social and Economic and Cultural Rights in its 2003 General Comment No 15 on the right to water. The right to water is not explicitly mentioned in the ICESCR, but the Committee considers it "falls within the category of guarantees essential for securing an adequate standard of living, particularly since it is one of the most fundamental conditions for survival" (para 3). "The right to water is also inextricably related to the right to the highest attainable standard of health (art. 12, para. 1) and the rights to adequate housing and adequate food" (art. 11, para. 1). The right to water encompasses personal sanitation, defined as the "disposal of human excreta" (p. 5, note 13).

\subsubsection{Gender Based Discrimination}

As a state party to CEDAW, India has a responsibility under international law to ensure that women enjoy an equal right to work. All three reports found that the women working on Assamese tea plantations did not fare as well as their male counterparts. Women were reported to be working almost exclusively as tea pluckers, with 80 percent of the plucking being done by female workers [3]. In contrast, men were given better paid clerical positions [3]. Employers were found to be systematically disregarding the definition of 'family' as laid down by the PLA [3]. Dependants of the female workers were excluded from access to benefits such as medical care or food rations despite the PLA explicitly including the spouses, children, and parents of both male and female workers.

Employers were found to frequently violate women's maternity protection rights regarding prenatal and postnatal care [3]. The GNRTFN report found that women were compelled to continue performing the same tasks throughout their pregnancies despite requesting a lighter workload [3]. As a result, the maternal mortality rates on tea plantations are alarmingly high. According to the Assam Human Development Report [39], the state has the highest levels of maternal mortality nationally, and one of the highest levels globally in specific regions such as the Upper Assam districts [16]. This goes against section 32 of the PLA, the Indian Maternity Benefits Act of 1961, ICESCR (Articles 1 and 12), CEDAW (Articles 11, 12, and 14 and General Recommendation 34), and the CRC (Article 24).

\subsubsection{Medical Facilities}

According to Section 10 of the PLA, medical facilities must be provided to workers and their families. All three reports found that workers did not have access to sufficient medical facilities. Appointed medical staff were observed to be treating workers' medical complaints with extreme callousness in the Columbia report [5]. It also noted that patients are required to present themselves at the clinic two or even three times to access sick leave to which they are entitled by law [5]. In cases of serious sickness, workers must travel approximately $20 \mathrm{~km}$ to reach the nearest state-run hospital [5]. The report indicated that despite the PLA directing plantations to have free medical facilities, there was often neither a health facility nor an ambulance available [5]. According to the workers interviewed, the management does not reimburse medical costs incurred when the workers visit the government health facilities [5]. As of August 2020, Indian media outlets have reported that the living conditions and lack of medical facilities on the plantations makes the workers extremely vulnerable to contracting Covid19 [40,41].

This is likely in violation of the right to health, guaranteed under Article 12 of the ICESCR, which states that State parties recognize "the right of everyone to the enjoyment of the highest attainable standard of physical and mental health". In 2000, the Committee on Economic, Social and Cultural Rights adopted its General Comment No. 14 on the right to the highest attainable standard of health, which breaks down the right to health in a number of key elements, many of which are likely to be violated in relation to Assam tea plantation workers, particularly availability, accessibility, and affordability (para. 12). 


\subsubsection{Wages}

Insufficient wages can be viewed as the root cause of the several problems faced by the workers. In the states of Assam and West Bengal, the living wage is determined through collective tripartite bargaining involving the state, tea planters' associations, and the workers' unions [3,5]. As a result, the wage in Assam (in 2015) was INR 122 per day [3]. In comparison, the minimum wage for an unskilled agricultural worker in India in 2015 was INR 222. Another issue faced by the workers is that of unfair deductions $[3,5]$. The Columbia and Sheffield reports identified various unjust deductions from the workers' payslips for reasons such as electricity, medical expenses, union dues, and expenses for religious celebrations (irrespective of the workers' religious views) [5,38]. Furthermore, the payslips were found to be written in English and most workers did not understand them [5]. The Sheffield report [38] found that many plantation business models were configured to minimise costs (and therefore increase profits) by underpaying workers.

Article 7 of the ICESCR protects the right to just and favourable conditions of work, which includes "remuneration which provides all workers, as a minimum, with: fair wages and equal remuneration for work of equal value without distinction of any kind (...) and a decent living for themselves and their families". The 2016 General comment No. 23 on the right to just and favourable conditions of work (article 7 of the International Covenant on Economic, Social and Cultural Rights) elaborates on this right. For the Committee, remuneration that provides a decent living must be understood as remuneration that is "sufficient to enable the worker and his or her family to enjoy other rights in the Covenant, such as social security, health care, education and an adequate standard of living, including food, water and sanitation, housing, clothing and additional expenses such as commuting costs". As seen above, many of those rights are violated for Assam tea plantation workers.

\subsubsection{Human Trafficking}

The Sheffield report found evidence indicating that women and girls were trafficked from tea estates into domestic and sex work in major cities such as Mumbai and Delhi [38] (p. 19). According to a report published by Stop the Traffik, a UK based organisation, human traffickers pose as employment agents and entice young people living on the tea estates of Assam to migrate to cities or groom parents to send children to cities on the promise of a better life [42]. Trafficked individuals were reported to be sold as domestic servants, poorly paid factory labour, or even sex workers [42]. It is difficult to capture the realities of human trafficking in and from Assam due to the absence of a composite quantitative database on human trafficking [43].

\section{Material and Methods}

For this case study, qualitative content analysis was applied. Content analysis is a technique frequently used by researchers in the social sciences to collect empirical evidence from documents containing social and environmental disclosure [44]. An important consideration in choosing this method was the fact that the data we worked with were unstructured and context sensitive. Working with content analysis offered the possibility to acknowledge the textuality of the data and to apply a common code to them, irrespective of their form. The methodology outlined by Krippendorff [45] was applied while coding and analysing the data and narrating the result.

We focused on the initiatives taken by six UK incorporated companies over the period from 2016 to August 2019: Tata Global Beverages, Unilever, Associated British Foods, Fortnum and Mason, Typhoo, and Bettys and Taylors Group. These companies were selected because they are the only tea businesses that cross the GBP 36 million turnover threshold set by the 2015 UK Modern Slavery Act for publishing a Modern Slavery Statement. Section 54 of the UK Modern Slavery Act (2015) on Transparency in Supply Chains clause (TISC) requires companies to report annually on how they have tackled modern slavery in their supply chains. Moreover, UK-based tea companies and retailers have 
immense influence in the supply chain and the global market, with both Unilever and Tata Tetley owning 10-20 percent of the global market share [46] (p. 37).

The dataset includes all modern slavery statements and corporate responsibility reports published by the six companies between 2015 and 2019. Modern slavery statements were retrieved from the Modern Slavery Registry run by the Business and Human Rights Resource Centre [47]. To create a comprehensive overview, we supplemented the modern slavery statements with any other documents that could have been used by the companies to make disclosures related to Assam. Documents such as human rights reports and social impact reports were retrieved by searching the consumer-facing and corporate websites of these companies. Whenever the websites mentioned Assam, it was taken into account and its context was analysed. Reports published by NGOs, research organisations, and other third parties that investigate the companies' connection with Assam are considered whenever available.

Qualitative data analysis software Atlas.ti was used to code and annotate the documents. We scanned the documents to check if they mentioned Assam at all. Where Assam was not mentioned, we looked at whether tea was mentioned, as we considered it was significant background information, although not directly relevant to answer our research question. Where links with Assam were disclosed, we looked at what was said. This allowed us to classify companies' approaches to the question of Assam in three categories: (a) Assam not mentioned; (b) Assam mentioned and corporate responsibility minimized; (c) Assam mentioned and corporate responsibility acknowledged. We considered that corporate responsibility was minimized when the companies remained vague about their links with Assam. By contrast, we considered that corporate responsibility was acknowledged when the company disclosed specific information.

All documents analysed to assess companies' approaches towards and relationship with Assam are listed in Table 1.

Table 1. Corporate accountability reports analysed in Section 4.

\begin{tabular}{|c|c|c|c|}
\hline Company & $\begin{array}{l}\text { Modern Slavery } \\
\text { Statements }\end{array}$ & Self-Published Reports & Third-Party Investigations \\
\hline Tata Global Beverages & $\begin{array}{l}\text { Statement I (2015-16) } \\
\text { Statement II (2016-17) }\end{array}$ & & $\begin{array}{l}\text { CAO Investigation of IFC } \\
\text { Environmental and Social } \\
\text { Performance in relation to: } \\
\text { Amalgamated Plantations } \\
\text { Private Limited (2016) } \\
\text { Solidaridad's independent } \\
\text { assessment of the APPL } \\
\text { action plan (2017) }\end{array}$ \\
\hline Unilever & $\begin{array}{c}\text { Statement I (2017) } \\
\text { Statement II (2018) } \\
\text { Statement III (2019) } \\
\text { Statement I (2016) }\end{array}$ & $\begin{array}{l}\text { Human Rights Report I (2015) } \\
\text { Human Rights Report II (2017) }\end{array}$ & \\
\hline Associated British Foods & $\begin{array}{l}\text { Statement II (2017) } \\
\text { Statement III (2018) } \\
\text { Statement IV (2019) }\end{array}$ & $\begin{array}{l}\text { Social Impact Report I (2016) } \\
\text { Social Impact Report II (2018) }\end{array}$ & \\
\hline $\begin{array}{c}\text { Fortnum and Mason } \\
\text { Typhoo }\end{array}$ & $\begin{array}{c}\text { Statement I (2018) } \\
\text { Statement I (2016) } \\
\text { Statement II (2018) } \\
\text { Statement I (2015-16) }\end{array}$ & & \\
\hline Bettys and Taylors Group & $\begin{array}{l}\text { Statement II (2016-17) } \\
\text { Statement III (2017-18) }\end{array}$ & & \\
\hline
\end{tabular}

\section{Results}

The paper now turns to tea companies. This section investigates what some of the world's largest tea businesses are doing to improve the situation in Assam by looking at what these companies themselves have published as well as other publicly available documents. Each company is considered in turn. 


\subsection{Tata Global Beverages}

Tata Global Beverages (TGB) is a UK incorporated multi-national group of companies and is the world's 2nd largest tea company. It is a part of the Tata group, which is among India's biggest multinational conglomerates. TGB reported a consolidated revenue of GBP 789 million for the financial year 2016/17 (Converted from Indian Rupees at the rate of 85.8 INR per GBP). Tetley, a widely consumed brand of tea in the UK, has been a wholly owned subsidiary of TGB since 2000. Besides Tetley, TGB also owns Tata tea, which is India's largest packaged tea brand. Vitax in Poland, Joekels in South Africa, Good Earth in the USA, Jemča in the Czech Republic, and Teapigs in the UK are the other tea brands owned by the company. TGB is operational across several countries in Europe, the Middle East and South Asia.

\subsubsection{International Financial Corporation's Investment}

In April 2009, the World Bank Group's International Financial Corporation invested USD 7.87 million in Tata Global Beverages' (TGB, formerly Tata Tea Limited, Mumbai, India) company Amalgamated Plantations Private Limited (APPL) [48]. The project was set up to acquire and manage 24 tea plantations located in Assam and its neighbouring state West Bengal [48]. The company promised to implement a sustainable employee-owned plantation model [48]. The company's shares are held by the management and employees of the company (15-20\%), TGB (19\%), IFC (19\%), and other investors the rest [48].

In 2011, Compliance Advisor Ombudsman (CAO), IFC's watchdog, received a complaint from the International Union of Food Workers (IUF) outlining concerns from unions representing workers on an APPL tea estate [49]. In 2012, the CAO Vice President authorised a compliance appraisal in relation to IFC's investment in APPL. In January 2013, CAO concluded that IFC's investment in APPL warranted a compliance investigation.

In February 2013, CAO received a complaint from three Indian non-governmental organizations (NGOs) on behalf of workers on three of APPL's plantations in Assam. The complaint raised concerns about living and working conditions on the APPL tea estates. The letter highlighted the long working hours, inadequate compensation, restrictions on freedom of association, poor hygiene and health concerns, poor living conditions, and inadequate protection for workers using pesticides. The complaint also raised concerns about a lack of consultation with the workers regarding the share program as well as IFC's decision not to apply its Indigenous Peoples policies to the tribal minorities who work on the tea estates. CAO completed an appraisal of the complaint in February 2014 and determined that the issues raised merited further inquiry. In 2016, CAO published a detailed report containing data from the investigation it carried out to ascertain if the APPL project had indeed violated certain social and environmental standards of the IFC.

In this report, CAO found that IFC's supervision of the investment in APPL did not meet the requirements of its sustainability policy or relevant internal procedures [49]. In particular, CAO found that IFC did not develop and retain the information needed to assess TGB's compliance with the performance standards as required [49]. In the context of the living conditions on the plantation, the report found that IFC did not assure itself that TGB was discharging its obligation to provide housing and other services in a manner that met the requirements of the relevant Performance Standards or those of Indian law [49]. The report also systematically answers all questions raised by civil society organisations and made suggestions to IFC regarding the steps needed to be taken for redress of the shortcomings in its adherence to social and environmental policies.

\subsubsection{Stake in Amalgamated Plantation Private Limited}

The Columbia report [5] as well as a BBC documentary about tea workers in Assam [50] specifically targeted APPL owned plantations and as a result, TGB faced backlash from its consumers around the world. At the time, TGB declared APPL to be a 'separate corporate entity' and declined to comment 
on the allegations [51]. TGB has worked systematically to dissociate all its brands from Assam tea. On consumer facing websites, none of TGB's products indicate the presence of Assam tea in their blend.

In 2017, Tetley Canada's website had a dedicated section that guaranteed its consumers that "Tetley tea purchased in Canada does not contain any tea from the APPL plantation in Assam" [52]. In the same year, Tetley UK's website still reassured consumers of the efforts being taken by TGB to improve the conditions on APPL's plantations in Assam and stated that "taking our business away from this area and these estates is not an option, as it would leave the workers without livelihoods or homes" [53]. In 2020, both websites no longer mentioned APPL or Assam.

TGB's corporate website mentions that TGB buys tea for its Indian products from APPL. However, Tata Tea's Indian website makes no mention of the situation in Assam or of APPL. It is likely that the lack of Indian media outlets covering the issue has resulted in insufficient awareness regarding the situation among Indian consumers and therefore TGB does not need to reassure its Indian consumers regarding its efforts towards improving the conditions on the APPL plantations.

Following the 'Who picked my tea?' campaign that targeted major UK-based tea companies, eight companies have declared the exact Assam plantations they source their tea from [54]. Tetley, owned by TGB, is one of them. As of July 2019, Tetley sourced tea from 68 estates in Assam.

\subsubsection{Solidaridad's Investigation of APPL Plantations}

In March 2014, TGB commissioned Solidaridad, an international civil society organisation, to conduct an assessment audit of the APPL plantations [55]. Solidaridad's assessment matched the one made by the Colombia report and the GNRTFN report on certain issues such as inadequate housing facilities, unavailability of functional latrines and bathing units, widespread malnutrition among workers, and lack of proper personal protection equipment for workers [56].

However, on several other issues, Solidaridad dismissed claims made by the previously mentioned reports. It states that APPL pays workers in accordance with the minimum wage standards set by the government and does not deduct any amount of money illegally [56]. In the case of medical facilities provided, the report suggests that "APPL was found to be providing best in class medical facilities in the estates" and that "the availability of doctors is more than required as per law" [56]. The report dismisses the problem of human trafficking on the plantations by addressing it as 'migration of young girls' and states that urban migration among young boys and girls in search of jobs is a social challenge [56].

In line with the recommendations of the Solidaridad assessment, APPL devised an action plan by the name of 'Project Unnati' to tackle the problematic areas identified in the report. The plan was backed by the IFC. However, various civil society organisations criticized it, as they perceived it as more relaxed regarding several burning social issues [57]. For example, Project AccountabiliTea, a combined effort by four civil society organisations, published photographic evidence from its June 2017 visit to three APPL plantations which indicates that unprotected pesticide spraying, substandard living conditions, contaminated drinking water, and lack of electricity were still a major problem on the plantations [57].

\subsubsection{Modern Slavery Statements}

TGB published a modern slavery statement for the financial years 2015-2016, 2016-2017, and 2017-2018. The latter is framed as an update of the other two. The 2015-2016 and 2016-2017 statements are almost identical in their content with the exception of a few details. The statements declare that "the vast majority of raw tea used to produce Tetley tea is sourced from Africa with the rest from various countries around the world". Neither of the statements mention the brand's association with Assam tea or APPL plantations. This comes across as a striking contrast with the in-depth description TGB provides on its corporate website regarding its effort to improve the situation on APPL plantations. The contents of the 2016-2017 statement differ from that of its predecessor on two aspects. Firstly, the 2015-2016 statement mentioned that TGB intended all its Tetley products to be Rainforest Alliance certified by the end of 2016. The 2016-2017 statement suggests that $86 \%$ of Tetley 
teas are Rainforest Alliance certified and that TGB is working towards full certification. The 2016-2017 statement does not mention the time frame for achieving this. The second difference between the two statements is that the latest statement mentions face to face training conducted in March 2017 for the Human Resources, Procurement, and Tea Buying departments regarding the issue of modern slavery and ways to identify and mitigate risks related to it. Both statements provide detailed information regarding TGB's affiliation with Ethical Tea Partnership, a non-profit organisation working to realise better working conditions for tea plantation workers around the world.

TGB's corporate website suggests that the company intends for all its tea to be $100 \%$ sustainably sourced by 2020. The website mentions TGB's intentions to source Rainforest Alliance certified tea only for Tetley-branded teas in Europe, Middle East, Africa, Canada, America and Australia, but excludes its brands that are sold in South Asia. TGB accepts independent third-party certifications of sustainable agricultural practices, such as Rainforest Alliance Certified, Trustea or UTZ, from their suppliers as evidence that the product they supply is sustainably sourced. The company is associated with the Ethical Tea Partnership, Rainforest Alliance, and Trustea for ethical sourcing from the point of view of (not only) fair labour and social practices.

On the whole, TGB mentions Assam, though not systematically, and does not fully acknowledge responsibility and remains vague as to the extent of their involvement with the human rights violations occurring on the ground.

\subsection{Unilever}

Unilever is a transnationally operating British-Dutch company specialising in consumer goods. It reported a consolidated revenue of GBP 47 billion (Converted from Euros at the rate of 0.89 Euro) in 2016 and is a FTSE 100 company. Unilever is presently the world's largest tea company. It has achieved this via acquisition of various tea companies over the past several decades. The origin of Unilever's tea business can be traced to the acquisition of Lipton tea by its Dutch predecessor company Van den Bergh in 1927. At present, the company owns 15 tea brands of varying sizes across several countries. Of these, Lipton, Brooke Bond, and PG tips are the most prominent.

\subsubsection{Unilever and Assam Tea}

Identifying whether Unilever uses tea from Assam in all its products is challenging because it does not have one single portal dedicated to its tea business. Upon searching its brands individually, the mention of Assam tea being used in certain products can be found on the websites of three of its brands-Brooke Bond Taj Mahal in India, PG Tips in the UK and Lipton in the USA. As per the list published as a part of the 'Who picked my tea?' campaign, Unilever's PG Tips sources Assam tea from 38 estates [54].

At the time of writing, Unilever has published two human rights reports. The first one was published in June 2015 [58] and the second in December 2017 [59]. The 2015 report acknowledges tea as an at-risk sector but does not mention Assam. The 2015 report focuses on the tea industry in Kenya and Turkey. The 2017 report, however, contains a section dedicated to the Assam tea industry and women's rights issues there. It acknowledges tea plantations in Assam to be part of Unilever's extended supply chain. The section 'Focus on Assam' identifies McLeod Russel as the company's supplier for Assam tea and provides details regarding the steps taken collectively by Unilever, McLeod Russel, and UN Women to improve the living and working conditions of female labourers working on Assam's tea plantations. Some of the issues addressed include sexual harassment and representations via women's forum and mothers' club. The report indicates that efforts for improvement are being implemented across six tea estates in Assam but does not provide any more information. It also mentions that Unilever joined the Ethical Tea Partnership in 2017.

A document from 2003 regarding the company's intentions to source sustainable tea mentions that "Unilever has tea estates in four tea growing regions of the world: Kenya, Northern India (Assam), 
Southern India, and Tanzania" [60]. However, no recent documents are available to confirm whether the company still owns plantations in Assam.

Unilever is a partner in The Seeds of Prosperity programme which is working towards improving the diets and hygiene of smallholder farmers. As per a blog post on Unilever's website, "a successful pilot has reached 2600 farmers in Tamil Nadu, India and the programme will now be replicated in tea farming communities in Assam as well as Kenya and Malawi, benefiting a further 300,000 people" [61].

A section dedicated to information regarding the company's sustainable sourcing practices in the tea industry mentions partnerships through which Unilever addresses "labour conditions on tea estates in regions such as Assam, India, where more needs to be done to eradicate unacceptable practices" [62]. There are no further details.

\subsubsection{Modern Slavery Statements}

Unilever presented its first modern slavery statement in January 2017 [47]. The report begins with the Chief Executive Officer's foreword which acknowledges the risk of forced labour in supply chains and mentions that Unilever knows that there is more that it can do to strengthen its 'process' and 'oversight' in the area. The statement does not specifically mention Assam but under the section titled 'assessing key risk areas', it discusses the tea sector and its susceptibility to the issue of forced labour. It states: "We believe that more must be done to improve conditions for tea estate workers and their families through working together with partners and others in the industry". The report goes on to explain that Unilever intends to tackle this issue by strengthening its certification models regarding labour rights and discloses that the company is working with the Rainforest Alliance to achieve this. Human trafficking is mentioned as one of the issues faced by tea communities that Unilever seeks to address. The section focusing on the risk of using third party labour acknowledges that the company outsources its work to labour providing contractors in Asia and Africa to a large extent. In contrast, the work outsourced in Europe, North and South America is done through a very limited number of contractors. As a solution to this problem, the statement says that the company is working to control the terms and conditions of third party contracted labour more closely. The statement also discusses the fact that despite conducting human rights impact assessments in certain parts of its supply chains and not identifying any forms of forced labour, Unilever remains vigilant about the risk of modern slavery in a rapidly developing market. It also provides information about Unilever's grievance mechanisms and tracking systems which, as per the statement, are the two pillars of tackling the issue of forced labour and human rights violations in supply chains.

Unilever's second modern slavery statement, published in April 2018, contains a paragraph on their tea supply chain. It mentions that Unilever joined the Ethical Tea Partnership and continues: "Our priority areas include improvements in housing and sanitation where we are focusing on our suppliers in Assam; increasing wages; enhancing safety; best practice sharing around model estates; and worker empowerment committees" [47]. What exactly that entails is not mentioned. In their latest report, published in March 2019, neither Assam nor their tea supply chain is mentioned [47].

Unilever's approach is therefore not straightforward. They definitely mention Assam, and some of the information they disclose is relatively precise, mentioning, for example, wages. By disclosing such information, we can say they acknowledge their responsibility to respect the human rights of Assam tea plantation workers. However, the lack of systematic disclosure regarding Assam also suggests they minimize their responsibility.

\subsection{Associated British Foods}

Associated British Foods (ABF) is an international food, ingredients and retail group operational across 50 countries in Europe, southern Africa, the Americas, Asia and Australia. ABF reported a consolidated revenue of GBP 15.4 billion in 2017 and is a FTSE 100 company [63]. It owns the popular tea brand Twinings, which is now an international brand with more than 200 teas sold in over 100 countries [48]. Twinings does not own any tea plantations but has manufacturing sites in UK, 
Poland, India and China. The tea used in the company's products is sourced from China, India, Kenya, Malawi, Sri Lanka, Argentina and Indonesia. In 1837, Queen Victoria granted Twinings a Royal Warrant and to date, Twinings has been supplying tea to every successive British Monarch's household [64]. The company sells Assam tea in both blended and non-blended forms.

\subsubsection{Associated British Foods and Assam Tea}

Twinings' UK website provides a link to its 'Sourced with Care' programme which aims to improve the living conditions of tea workers who are a part of Twinings' supply chain. As a part of the programme, social impact reports were published in 2016 and 2018. The 2016 report highlights the various initiatives taken by Twinings and their impact [65]. Both reports mention that Twinings does not directly employ tea plantation workers in any country $[65,66]$. In 2016, the company sourced $15 \%$ of its tea from India, and in 2018, $18 \%$. Both reports also state that Twinings has full traceability in its supply chain and knows exactly from which estates its raw material is sourced from.

The 2016 report discusses two projects undertaken by Twinings in Assam. The report does not disclose the names of the tea estates where both these projects are operational. The first project in Assam commenced in 2010 as partnership between United Nations Children's Fund (UNICEF), the Assam branch of the Indian Tea Association, and Twinings. The project focused on improving the quality of life for girls residing on tea estates. In 2014, the project changed its focus from nutrition to child protection. At present, the project has been implemented in 63 tea gardens, where it has established adolescent girls' clubs and child protection committees. The report claims that the project has been successful in reducing anaemia among young girls by $14 \%$. The second project commenced in 2015 in partnership with Mercy Corps. It aimed to promote the adoption of clean, fuel-efficient cook stoves among workers on three tea estates in Assam. The project expected to improve the air quality in homes, reduce the burden of collecting firewood, and reduce the incidences of smoke-related respiratory and eye problems. The report states that as of 2016, 807 households have adopted clean cook stoves, and this has improved the quality of life for 4800 people. It does not provide statistical results regarding any of the areas the project aimed to improve. The 2018 Report mentions Assam several times. It reads: “Twinings support for UNICEF in Assam, India, has enabled UNICEF to strengthen its working relationship with the government in Assam, which has resulted in UNICEF being able to provide training and technical support for social workers, health officers, teachers, police and government services. The outcome of this is a stronger child protection system-not only in tea communities but across the state". [66] It is not specified what "support for UNICEF" means in practice. In 2018, the UNICEF programme was extended to women and maternal healthcare while also keeping its focus on young children, especially girls. The programme with MercyCorps was also still in place in 2018, and the report explains how in 2017 it was expanded to include water, sanitation and hygiene.

As per the list published as a part of the 'Who picked my tea?' campaign, $\mathrm{ABF}^{\prime} \mathrm{s}$ Twinings sources tea from 25 estates in Assam [54].

\subsubsection{Modern Slavery Statements}

ABF has published four modern slavery statements so far [47]. The first three statements make no mention of Assam. In the latest statement, ABF mentions that Twinings has specific partnerships in place in various regions, one of them being UNICEF in Assam, which help it to identify and remediate potential issues.

ABF's work in Assam suggests they acknowledge their responsibility towards tea plantation workers. However, their approach is not systematic and focuses only on certain issues. This can be interpreted as minimizing their responsibility to respect human rights under the UN Guiding Principles. 


\subsection{Fortnum and Mason}

\subsubsection{Background}

Fortnum and Mason (F\&M) is a luxury department store located in Piccadilly, London. Established in 1707, the company owns two other stores in London and one in Dubai as well as diverse hospitality ventures. It is privately owned by Wittington Investments Ltd. (London, UK) and reported a consolidated revenue of GBP $112.9 \mathrm{~m}$ for the financial year 2016-2017 [67].

\subsubsection{Fortnum and Mason and Assam tea}

F\&M sells Assam tea in various forms through its website and stores. F\&M's latest CSR report mentions that "all Fortnum \& Mason teas from India and China are sourced from tea estates and producer groups participating in and adhering to Ethical Tea Partnership (ETP) standards" [68]. The report makes no further comments regarding F\&M's tea suppliers or supply chain.

\subsubsection{Modern Slavery Statements}

F\&M has so far published one modern slavery statement, in 2018 [47]. With regard to tea, it only mentions that the company is a member of the ETP. There is no mention of Assam.

\subsection{Typhoo}

\subsubsection{Background}

Typhoo Tea Ltd. (Merseyside, UK) is the third largest producer of tea in the UK. The brand was introduced to the British markets in the early 1900s. In 2005, Apeejay Surrendra Group, an Indian business conglomerate, bought Typhoo from Premier Foods and is now jointly owned by Apeejay and Global Tea \& Commodities. The company reported a revenue of GBP 70 million for the financial year 2017-2018 [69]. The parent company operates a subsidiary of Typhoo in India by the name of Typhoo India. Typhoo's retail spans over 50 countries globally.

\subsubsection{Typhoo and Assam Tea}

Several black teas sold by Typhoo mention the use of Assam tea in their blend. The Apeejay Surrendra Group owns 17 tea estates in the Tinsukia, Dibrugarh, Charaideo, Udalguri and Sonitpur districts of Assam. These estates are spread over 50,000 acres and are operated by three companies-Assam Frontier, Empire, and Singlo. According to Apeejay's website, the estates are ISO 9001:2008 certified and are under the Ethical Tea Partnership. Two premium estates are HACCP certified, 11 estates are Rainforest Alliance certified, and 12 estates have a Trustea certification. The company's website does not provide any further information about the basis for this differentiation in certification schemes, nor does it explicitly mention the use of tea from these estates in domestic or British Typhoo products.

Apeejay's website mentions that welfare of plantation communities is 'core priority' and that the multiple social welfare programmes initiated in and around tea estates reflect this. The company also states, "As a non-state actor and a tea producer, we aspire to deliver on UN Sustainable Development Goals and have aligned our policy towards activities that deliver the targets-Life on Land, Climate Action, Gender Equality, Clean Water and Sanitation (SDGs 15, 13, 5, and 6 respectively)".

Typhoo UK's Sustainability page mentions that all tea used by Typhoo is sourced from Rainforest Alliance-certified farms. It also states that Typhoo was one of the first tea companies to send their buyers to monitor various aspects of life on tea estates. Typhoo Tea Ltd. is a member of the Ethical Trading Initiative.

As per the list published as a part of the 'Who picked my tea?' campaign, Typhoo sources tea from 35 estates in Assam [54]. 


\subsubsection{Modern Slavery statements}

Typhoo's latest modern slavery statement, released in July 2018, discusses the steps taken by the company to mitigate the risk of modern slavery within their organisation as well as in their extended supply chain [70]. It discloses that Typhoo sources teas from 14 countries and around $1 / 5$ th of all tea is sourced from India. It also mentions that products are purchased both privately and through public auction but only via approved suppliers. The said suppliers are approved based on their membership of SEDEX, Fairtrade, Rainforest Alliance, or Ethical Tea Partnership. The company acknowledges that many of the countries that they source tea from have "well publicised historic incidents of abuse of human rights and labour laws". This is an odd choice of words, given the human rights violations occurring in Assam and suggest they are minimizing their responsibility. The report goes on to state that Typhoo is committed to uncovering and remedying any modern slavery and human trafficking that might exist in its supply chain. The report mentions that the company is actively supporting a UNICEF project in Assam which aims to eliminate child trafficking and exploitation, without further detail about what they do exactly.

A salient feature of the report is its list of objectives and actions that the company aimed to fulfil by various dates ranging from 2017 to 2019 . Out of 15 objectives, the company candidly reported that only one third (5) were fulfilled, while the other ten were a work in progress. This rare level of transparency in the tea supply chain is to be commended.

Typhoo's modern slavery statement from 2016 does not mention Assam [47]. On the whole, however, there is little detail provided and we cannot conclude that they fully acknowledge their responsibility to respect human rights.

\subsection{Bettys and Taylors Group}

Bettys and Taylors Group (BTG) is a Yorkshire-based family business that owns three tea brands sold in the UK-Taylors of Harrogate, Bettys, and Yorkshire Tea. Taylors of Harrogate holds a Royal Warrant and is an official supplier to the household of the Prince of Wales. The company was founded in 1962 due to a merger between an establishment by the name of Bettys Tea Room and tea and coffee merchants Taylors of Harrogate. BTG reported a revenue of GBP 173.6 million for the financial year 2015-2016 [71].

\subsubsection{Bettys and Taylors Group and Assam Tea}

Bettys, as well as Yorkshire Tea, mention the use of Assam tea as a part of their various tea blends. The group's corporate website as well as individual brand websites express commitment towards the responsible sourcing of tea. The corporate website mentions that BTG works closely with Ethical Tea partnership to develop cohesive plantation communities in Assam. Issues regarding housing, sanitation, and education are among the issues that the project aims to address. BTG is also a part of a project that seeks to understand wage issues in the tea industry. The project focuses on Malawi, Indonesia, and India. No further information is provided about the specific region in India that the project seeks to address.

Yorkshire Tea's website includes a page that provides details regarding the various projects supported by the brand [72]. The page mentions a project developed in collaboration with the Ethical Tea Partnership which is likely to be the same as the one mentioned on BTG's corporate website. The said project has been functional since 2016 and aims to set up community development forums $(\mathrm{CDFs})$ on four tea estates. The forum consists of elected representatives from the estate's working and non-working population, community groups, unions and management. The forum works on issues such as housing repairs, access to water, access to latrines, and improving financial literacy levels. The CDFs seek to officially register themselves as societies so that they can access government funding and work. Yorkshire Tea has invested GBP 100,000 into the project. Yorkshire Tea is a part of another project in partnership with UNICEF, the Ethical Tea Partnership, and other tea companies to help 
improve child protection policies on Assam's tea estates. The website mentions that the brand donated GBP 2000 towards installing household water filters at four estates in the Moran district of Assam.

As per the list published by the 'Who picked my tea?' campaign, BTG's Yorkshire Tea sources tea from 14 estates in Assam [54].

\subsubsection{Modern Slavery Statements}

At the time of writing, the company had published three modern slavery statements [47]. In their first statement, they explained that they did not identify any instances of modern slavery in their operations or supply chain; the statement goes on to acknowledge that this does not mean that the company can guarantee the absence of modern slavery in its business. Sourcing black and specialty tea is recognized as a high-risk business activity due to documented instances of trafficking and rural poverty in the Assam and Darjeeling regions of North India. The UNICEF-ETP project mentioned above is also discussed in this statement and the two subsequent statements. In order to mitigate this risk, the company sources all its tea from third party certified farms. The statement lists Rainforest Alliance, Fairtrade, and UTZ as its trusted certification schemes. Bettys and Taylors group's sourcing policy is based on a direct relationship model that supports long-term forward supply contracts, high levels of supply chain transparency, and regular face-to-face contact with suppliers. The statement explains the company's risk assessment process which was developed in 2016. The aim of this process is to enable decision makers to identify those aspects of business that are at a risk of facilitating modern slavery. The 2017 statement includes a section titled "What we said we'd do in 2017", which reveals they had committed to "disclose any instances of modern slavery, along with corrective actions taken". However, the statement does not contain any mention of possible instances, or even a sentence indicating that they did not find any such instance. The 2018 statement contains no commitment of this kind. However, under the heading "significant residual risks and gaps", it reads: "Documented incidences of trafficking within high risk groups in some geographies we trade with, primarily North India (Assam)". No further details are provided. This reads like a missed opportunity to fully acknowledge responsibility towards these "high risk groups".

\section{Discussion}

Out of the 15 modern slavery statements we analysed, only five mentioned Assam-Unilever 2018, Associated British Foods 2019, Typhoo 2018, Bettys and Taylors Group 2016, Bettys and Taylors Group 2018. However, some companies did acknowledge their responsibility towards Assam to a limited extent via other self-published documents. If the six companies were to be ranked based on how much they divulge regarding their involvement with the situation in Assam, Unilever would be at the forefront. The company's acknowledgement of human rights issues in its supply chain and partial transparency regarding specific actions taken to improve the situation in Assam makes its disclosure more lucid in comparison to the other companies. Associated British Foods comes next. Like Unilever, $\mathrm{ABF}$ does acknowledge that it sources tea from Assam and mentions initiatives that it supports to improve the situation on the ground. However, $\mathrm{ABF}^{\prime} \mathrm{s}$ modern slavery statements do not mention Assam at all. Therefore, it has been placed second. Typhoo ranks third with its 2018 modern slavery statement mentioning that the company sources from Assam. The statement discloses the company's involvement in social development programmes in the region but without providing any further details. Bettys and Taylors group ranks fourth. While the company acknowledges that sourcing tea from Assam is risky, it concludes that its supply chains are free from modern slavery. The company's initiative to improve the working conditions in Assam is framed as a CSR project rather than an effort to address human rights issues in its supply chains. It is, however, interesting to note that Bettys and Taylors group is the only company that mentions Assam in more than one modern slavery statement. Fortnum and Mason does not disclose any links with Assam and therefore ranks fifth. One can only speculate that the company does source from the region because it sells products containing Assam tea. Tata Global Beverages performs the most poorly and therefore ranks last. The company has 
a well-publicised history of dissociating with Assam tea plantations and its modern slavery statements and other publications reflect the same.

Our finding is that the companies under examination avoid the problems of Assam by reporting on other issues, or by reporting on those issues in a superficial and selective way. This article aimed to answer the following research question: in a context where the existence of human rights violations at the end of the supply chain is well-documented, how do companies reconcile their possible connection with those violations and the corporate responsibility to respect human rights under the UN Guiding Principles on Business and Human Rights? When Sections 2.2 and 4 are compared, it is clear that reports by businesses and civil society organisations render the situation in Assam differently. Although some tea companies pay attention to Assam and have supported or devised specific programmes to address some of the salient human rights issues in the region, there is no systematic tackling of the issues, and some companies seemingly do nothing at all. This is an important finding because, given how serious and publicized those issues are, one could have expected companies to pay more attention to them, and reports to reflect on them. Instead, reports remain as evasive about Assam as they are about other human rights issues [13]. Selective disclosure is at play even when human rights issues connected to the companies are well-documented [73].

In a piece published in 2015, Ramasastry contrasted the corporate social responsibility (CSR) and business and human rights (BHR) approaches. She noted that "CSR focuses on individual company decision making - what human rights scholars and activists might view as an à la carte view of human rights" [74]. Reporting alone encourages this because with limited external checks on the contents of the documents being published, companies essentially report on what they choose to report on, and naturally simplify issues and present them in a flattering way for themselves. Our findings confirm this shortcoming but also suggest that, from the perspective of rights-holders, it may be even more problematic than previously thought. The situation in Assam is severe and the links with tea companies is clear. Yet, and this is this article's main contribution, it appears that even in those circumstances, disclosures are grossly underestimating the issues. Thus, overall, we argue that the CSR approach under which companies pick and choose what they want to focus on, often without explanation, is not suitable when it comes to avoiding human rights impacts. By contrast, a BHR approach, resting on the UN Guiding Principles on Business and Human Rights, focuses on internationally defined human rights, and on how companies should act in order to avoid impacting them [75]. A BHR approach considers any violation of human rights to be one too many and encourages companies to systematically map out, prevent and address all instances of abuse.

\subsection{Limitations}

The empirical results reported in this study should be considered in the light of some limitations. First, it was impossible to accurately assess whether companies that do not mention Assam in their modern slavery reports and other publications actually discharge their responsibility to respect the human rights of workers from the region. Public disclosure is limited to what the companies wish to share and may not accurately display the full extent of their involvement in Assam's situation. This limitation is somewhat mitigated by the fact that the corporate responsibility to respect human rights under the UNGPs mandates companies to communicate about their actions. Thus, doing without communicating violates the UNGPs, though admittedly this violation is less severe than the one resulting from not doing anything.

Second, the reports describing the workers' situation and those containing the companies' public disclosures were published during slightly different timelines. To describe the situation on the ground, we refer to reports published between 2014 and 2018, whereas the corporate reports we analyse were published between 2016 and 2019. However, a 2019 report published by Oxfam confirms that the situation on the tea plantations has remained unchanged [76]. The results from this report describe the workers' living and working situation in a manner that is essentially the same as the three reports used in this study. 


\subsection{Implications and Future Research}

Corporate reporting following a CSR approach does not allow companies to meet their responsibility to respect human rights. This raises serious questions about reporting as a tool for corporate accountability. In a situation such as Assam tea plantations, where the human rights abuse is systematic, large scale and well-documented, we as researchers are equipped to compare the reports and the situation. This is the task we undertook in this article. This comparison has revealed important shortcomings with the current approach. It would be interesting in further research to see if our findings are confirmed in other similar situations as well. How do companies report on their association with other well-documented human rights issues?

More broadly, beyond our own study and similar future studies, our findings have further implications. Since reporting on situations that are well-documented seems inadequate, how can we trust companies reporting on situations that are not well-documented, and that they are nevertheless supposed to cover in their disclosures? Our findings suggest that reporting, at least reporting alone, is not an appropriate tool to address large-scale human rights issues up the supply chain. This is not to say it serves no purpose [77] (p. 554), but rather to highlight its inherent limitations.

\section{Conclusions}

Our analysis shows that the gap between the situation on the ground and what companies report on Assam is striking. Most companies minimize their responsibility to respect the human rights of Assam tea plantation workers. This is so despite a clear responsibility under Guiding Principle 21 to communicate externally "how they address their human rights impacts ( ... ) particularly when concerns are raised by or on behalf of affected stakeholders. Business enterprises whose operations or operating contexts pose risks of severe human rights impacts should report formally on how they address them".

Using a bottom-up approach, this article has taken human rights violations on the ground as a starting point. Showing how key companies who procure raw material from the region have communicated and acted on these issues is its main empirical contribution. The data suggest that from the perspective of advancing the protection of rights-holders, corporate disclosures are of limited value. In this sense, our findings confirm the findings of other studies that have noted the inherent limitations and at times counter-productive effects of corporate reporting, even when such reporting is mandated by law, as is the case, for example, under the UK Modern Slavery Act $[11,13]$. Moreover, this article has also advanced previous knowledge by focusing on reporting on well-documented human rights issues. This has allowed us to compare the contents of corporate disclosures with what we already knew about the human rights issues on the ground, rather than take the disclosures at face value.

It appears from the documents we have analysed that companies have embraced a CSR approach in their treatment of Assam workers. This is not to say they have done nothing to tackle their human rights issues. It means, however, that none of them have made the systematic tackling of these issues their absolute priority. In cases like Assam, where human rights violations have been rampant for over a century, mitigation strategies based merely on societal expectations and market forces are insufficient [75]. It is argued here that in order to make a durable impact on the human rights of Assam tea plantation workers, businesses need to make the shift from a CSR approach to a BHR approach. This shift may happen soon, at least for European companies. Several European countries, as well as the European Union, are currently considering the adoption of human rights due diligence legislation [78]. Such legislation, possibly modelled after the French Loi sur le devoir de vigilance [79], embraces a BHR approach by requiring companies not only to report but to act to prevent, mitigate and redress human rights violations throughout their supply chains. This novel approach, embedding the UN Guiding Principles into law, could be a game-changer for Assam workers. 
Supplementary Materials: The following are available online at http://www.mdpi.com/2071-1050/12/18/7409/s1, Table S1: Summary of reports.

Author Contributions: Conceptualization, M.R. and N.B.; methodology, M.R. and N.B.; software, M.R.; validation, N.B.; formal analysis, M.R.; data curation, M.R.; writing-original draft preparation, M.R.; writing-review and editing, N.B.; supervision, N.B. All authors have read and agreed to the published version of the manuscript.

Funding: This research received no external funding.

Acknowledgments: The authors wish to thank Lin Batten for her editorial assistance and the anonymous reviewers for their comments and suggestions.

Conflicts of Interest: The authors declare no conflict of interest.

\section{References}

1. United Nations (UN). Guiding Principles on Business and Human Rights: Implementing the United Nations "Protect, Respect and Remedy" Framework; A/HRC/17/31; United Nations: New York, NY, USA, 2011.

2. Food and Agriculture Organization (FAO). World Tea Production and Trade: Current and Future Development. 2015. Available online: http://www.fao.org/3/a-i4480e.pdf (accessed on 13 July 2020).

3. Global Network for the Right to Food and Nutrition (GNRTFN). A Life without Dignity-The Price of Your Cup of Tea. 2016. Available online: http://www.iuf.org/w/sites/default/files/FFMFINALReport_160616_web.pdf (accessed on 13 July 2020).

4. Sharma, J. 'Lazy' natives, coolie labour, and the Assam tea industry. Mod. Asian Stud. 2009, 43, $1287-1324$. [CrossRef]

5. Rosenblum, P.; Sukthankar, A. The More Things Change; The World Bank, Tata and Enduring Abuses on India's Tea Plantations; Columbia Law School Human Rights Institute: New York, NY, USA, 2014; Available online: https://web.law.columbia.edu/sites/default/files/microsites/human-rights-institute/files/tea_report_ final_draft-smallpdf.pdf (accessed on 13 July 2020).

6. Gupta, B.; Swamy, A. Unfree Labour: Did Indenture Reduce Labour Supply to Tea Plantations in Assam? Competitive Advantage in the Global Economy online Working Papers Series. 2013. No. 177. Available online: https://econpapers.repec.org/paper/cgewacage/177.htm (accessed on 13 July 2020).

7. Rowlatt, J.; Deith, J. The Bitter Story behind the UK's National Drink. BBC News. 2015. Available online: https://www.bbc.com/news/world-asia-india-34173532 (accessed on 13 July 2020).

8. European Parliament. Access to Legal Remedies for Victims of Corporate Human Rights Abuses in Third Countries. 2019. Available online: https:/www.europarl.europa.eu/thinktank/en/document.html?reference= EXPO_STU(2019)603475 (accessed on 13 July 2020).

9. Roorda, L. Jurisdiction over Foreign Direct Liability Claims against Transnational Corporations in EU Member States. Ph.D. Thesis, University of Utrecht, Utrecht, The Netherlands, 2019.

10. Palombo, D. The duty of care of the parent company: A comparison between French law, UK precedents and the Swiss proposals. Bus. Hum. Rights J. 2019, 4, 265-286. [CrossRef]

11. Mares, R. Corporate transparency laws: A hollow victory? Neth. Q. Hum. Rights 2018, 36, 189-213. [CrossRef]

12. Sierra-Garcia, L.; Garcia-Benau, M.; Bollas-Araya, H. Empirical analysis of non-financial reporting by Spanish companies. Adm. Sci. 2018, 8, 29. [CrossRef]

13. Monciardini, D.; Bernaz, N.; Andhov, A. The organizational dynamics of compliance with the UK Modern Slavery Act in the food and tobacco sector. Bus. Soc. 2019, 1-53. [CrossRef]

14. Stevenson, M.; Cole, R. Modern slavery in supply chains: A secondary data analysis of detection, remediation and disclosure. Supply Chain Manag. Int. J. 2018, 12, 81-99. [CrossRef]

15. Hampton, D. Modern slavery in global supply chains: Can National Action Plans on business and human rights close the governance gap? Bus. Hum. Rights J. 2019, 4, 239-263. [CrossRef]

16. Edelman, L.B. Working Law: Courts, Corporations, and Symbolic Civil Rights; University of Chicago Press: Chicago, IL, USA, 2016.

17. Bernaz, N. Business and Human Rights: History, Law and Policy-Bridging the Accountability Gap; Routledge: London, UK; New York, NY, USA, 2016.

18. Neglia, M. The UNGPs-Five years on: From consensus to divergence in public regulation on business and human tights. Neth. Q. Hum. Rights 2016, 34, 289-317. [CrossRef] 
19. Augustein, D.; Dawson, M.; Thielbörger, P. The UNGPs in the European Union: The open coordination of business and human rights? Bus. Hum. Rights J. 2018, 3, 1-22. [CrossRef]

20. Bonnitcha, J.; McCorquodale, R. The concept of 'due diligence' in the UN Guiding Principles on business and human rights. Eur. J. Int. Law 2017, 28, 899-919. [CrossRef]

21. Buhmann, K. Business and human rights: Understanding the UN Guiding Principles from the perspective of transnational business governance interactions. Transnatl. Leg. Theory 2015, 6, 399-434. [CrossRef]

22. O'Brien, C. Transcending the binary: Linking hard and soft law through a UNGPS-Based Framework Convention. Ajil Unbound 2020, 114, 186-191. [CrossRef]

23. McConnell, L. Assessing the feasibility of a business and human rights treaty. Int. Comp. Law Q. 2017, 66, 143-180. [CrossRef]

24. Bilchitz, D. The necessity for a business and human rights treaty. Bus. Hum. Rights J. 2016, 1, $203-227$. [CrossRef]

25. Bernaz, N.; Pietropaoli, I. Developing a business and human rights treaty: Lessons from the deep seabed mining regime under the United Nations Convention on the Law of the Sea. Bus. Hum. Rights J. 2020, 1-21. [CrossRef]

26. Schrempf-Stirling, J.; van Buren, H.J. Business and human rights scholarship in social issues in management: An analytical review. Bus. Hum. Rights J. 2020, 5, 28-55. [CrossRef]

27. Fasterling, B.; Demuijnck, G. Human rights in the void? Due diligence in the UN Guiding Principles on Business and Human Rights. J. Bus. Ethics 2013, 116, 799-814. [CrossRef]

28. Davitti, D. The rise of private military and security companies in European Union migration policies: Implications under the UNGPs. Bus. Hum. Rights J. 2019, 4, 33-53. [CrossRef]

29. Abe, $\mathrm{O}$. The feasibility of implementing the United Nations guiding principles on business and human rights in the extractive industry in Nigeria. J. Sustain. Dev. Law Policy 2016, 7, 137-157. [CrossRef]

30. Lindsay, R.; McCorquodale, R.; Blecher, L.; Bonnitcha, J.; Crockett, A.; Sheppard, A. Human rights responsibilities in the oil and gas sector: Applying the UN Guiding Principles. J. World Energy Law Bus. 2013, 6, 2-66. [CrossRef]

31. de Felice, D. Banks and human rights due diligence: A critical analysis of the Thun Group's discussion paper on the UN Guiding Principles on Business and Human Rights. Int. J. Hum. Rights 2015, 19, 319-340. [CrossRef]

32. van Ho, T.L.; Alshaleel, M.K. The mutual fund industry and the protection of human rights. Hum. Rights Law Rev. 2018, 18, 1-29. [CrossRef]

33. Moon, S. Respecting the right to access to medicines: Implications of the UN Guiding Principles on Business and Human Rights for the pharmaceutical industry. Health Hum. Rights J. 2013, 15, 32-43.

34. Zayets, V. Implementation of the UN Guiding Principles on Business and Human Rights in agribusiness with respect to lessons in the extractive sector. Law Rev. Kyiv Univ. Law 2016, 4, 414-422.

35. Schliemann, C.; Terwindt, C. Guest editorial: Agribusiness and accountability. Bus. Hum. Rights J. 2019, 4, 317-321. [CrossRef]

36. Hubers, F.; Thijssens, T. Human rights reporting under increasing institutional pressure. Maandbl. Voor Account. En Bedrijfsecon. 2020, 94, 303-312. [CrossRef]

37. Nikolaeva, R.; Bicho, M. The role of institutional and reputational factors in the voluntary adoption of corporate social responsibility reporting standards. J. Acad. Mark. Sci. 2011, 39, 136-157. [CrossRef]

38. LeBaron, G. The Global Business of Forced Labour: Report of Findings; SPERI \& University of Sheffield: Sheffield, UK, 2018; Available online: http://globalbusinessofforcedlabour.ac.uk/wp-content/uploads/2018/05/Reportof-Findings-Global-Business-of-Forced-Labour.pdf (accessed on 13 July 2020).

39. United Nations Development Programme (UNDP). Assam Human Development Report. 2014. Available online: https://www.in.undp.org/content/dam/india/docs/Assam_HDR_2014.pdf (accessed on 13 July 2020).

40. Sen, S. COVID-19 Has Pushed India's Already Suffering Tea Plantation Workers into Deeper Crisis. The Wire. 2020. Available online: https:/thewire.in/labour/covid-19-lockdown-tea-workers-labour (accessed on 13 August 2020).

41. Saha, A. Wary of Large-Scale Spread, Assam Keeps Close Watch on Tea Gardens. The Indian Express. 2020. Available online: https://indianexpress.com/article/india/wary-of-large-scale-spread-assam-keeps-closewatch-on-tea-gardens-6533463/ (accessed on 13 August 2020).

42. Quinn, T. Not My Cup of Tea. Stop the Traffic. 2017. Available online: https://static1.squarespace.com/static/ 5600d036e4b056134c4419f3/t/5627226ee4b00b89a67288b8/1445405294903/Not+my+Cup+of+Tea+report+ FINAL.pdf (accessed on 13 July 2020). 
43. UNICEF. Report: Secondary Data Analysis on Trafficking of Women and Children in Assam. 2014. Available online: https:/scpsassam.org/wp-content/uploads/2017/11/Assam-trafficking-report-March-2014.pdf (accessed on 13 August 2020).

44. Guthrie, J.; Abeysekera, I. Content analysis of social, environmental reporting: What is new? J. Hum. Resour. Costing Account. 2006, 10, 114-126. [CrossRef]

45. Krippendorff, K. Content Analysis: An Introduction to Its Methodology; Sage: Thousand Oaks, CA, USA, 2004.

46. CORE. Risk Averse? Company Reporting on Raw Material and Sector-Specific Risks under the Transparency in Supply Chains Clause in the UK Modern Slavery Act 2015. 2017. Available online: https://corporate-responsibility.org/risk-averse-company-reporting-raw-material-sector-specificrisks-transparency-supply-chains-clause-uk-modern-slavery-act-2015/ (accessed on 13 July 2020).

47. Modern Slavery Registry. Available online: https://www.modernslaveryregistry.org (accessed on 15 July 2020).

48. IFC Project Information Portal Tata Tea. 2017. Available online: https://disclosures.ifc.org/\#/projectDetail/ SPI/25074 (accessed on 13 July 2020).

49. Compliance Advisor Ombudsman (CAO). CAO Investigation of IFC Environmental and Social Performance in Relation to: Amalgamated Plantations Private Limited (APPL), India. 2016. Available online: http://www.caoombudsman.org/cases/document-links/documents/CAOInvestigationReportofIFCinvestmentinAPPL_EN.PDF (accessed on 13 July 2020).

50. Deith, J. Inside the Tea Gardens of Assam. BBC Newws. 2015. Available online: http://www.bbc.co.uk/programmes/ p0339lyz (accessed on 13 July 2020).

51. Nelson, D. Abused Workers Toil for Tetley Tea. The Telegraph. 2014. Available online: http://www.telegraph.co. uk/news/worldnews/asia/india/10634065/Abused-workers-toil-for-Tetley-tea.html (accessed on 13 July 2019).

52. Tetley. Sustainability. 2017. Available online: http://www.tetley.ca/en/about-us/sustainability (accessed on 7 December 2017).

53. Tetley. In Response to BBC Story on Living and Working Conditions in Assam. 2015. Available online: https://www.tetley.co.uk/bbc-assam (accessed on 7 December 2017).

54. Traidcraft Exchange. Who Picked My Tea? 2019. Available online: https://traidcraftexchange.org/tea-answers (accessed on 1 April 2020).

55. Solidaridad. Solidaridad to Conduct Independent Assessment of APPL Tea Gardens in India. 2014. Available online: https://www.solidaridadnetwork.org/news/solidaridad-to-conduct-independent-assessment-ofappl-tea-gardens-in-india (accessed on 15 July 2020).

56. Solidaridad. Independent Assessment of the APPL Action Plan. 2017. Available online: https://amalgamatedplantations. co.in/pdf/APPL-assessment-Executive-Summary.pdf (accessed on 15 July 2020).

57. Project AccountabiliTea. Is the World Bank keeping Its Promises to Indian Tea Workers? 2017. Available online: http://www.accountabilitea.org/wp-content/uploads/2017/08/Project-AccountabiliTEA_FINAL.pdf (accessed on 15 July 2020).

58. Unilever. Enhancing Livelihoods, Advancing Human Rights-Human Rights Report 2015. 2015. Available online: https://www.unilever.com/Images/unilever-human-rights-report-2015_tcm244-437226_en.pdf (accessed on 14 July 2020).

59. Unilever. Human Rights Progress Report 2017. 2017. Available online: https://www.unilever.com/Images/ human-rights-progress-report_tcm244-513973_en.pdf (accessed on 14 July 2020).

60. Unilever. Tea-A Popular Beverage. 2003. Available online: https://www.unilever.com/Images/es_2003_teaa-popular-beverage_tcm244-409725_en.pdf (accessed on 15 July 2020).

61. Unilever. Improving the Nutrition and Hygiene of Smallholder Farmers. 2017. Available online: https://www.unilever. com/news/news-and-features/Feature-article/2017/Improving-the-nutrition-and-hygiene-of-smallholder-farmers.html (accessed on 15 July 2020).

62. Unileve. Sustainable Living Report. 2017. Available online: https://www.unilever.com/Images/sustainableliving-report-2017_tcm244-537865_en.pdf (accessed on 15 July 2020).

63. Companies House. Associated British Foods Plc. 2017. Available online: https://beta.companieshouse.gov. uk/company/00293262/filing-history (accessed on 14 July 2019).

64. Twinings. History of Twinnings. 2017. Available online: https://www.twinings.co.uk/about-twinings/history-oftwinings (accessed on 14 July 2019).

65. Twinings. Twinings Social Impact Report. 2016. Available online: https://www.sourcedwithcare.com/en/library/ (accessed on 14 July 2019). 
66. Twinings. Twinings Social Impact Report. 2018. Available online: https://www.sourcedwithcare.com/en/library/ (accessed on 14 July 2019).

67. Companies House. Fortnum and Mason Public Limited. 2017. Available online: https://beta.companieshouse. gov.uk/company/00084909/filing-history (accessed on 14 July 2019).

68. Fortnum \& Mason. Sustainability \& Social Responsibility Report. 2018. Available online: https://assets. fortnumandmason.com/cms-assets/ZNr15gZbRCFDEJraGeQP_FM_Sustainability_Report_v4.pdf (accessed on 14 July 2019).

69. Companies House. Typhoo Tea Limited. 2017. Available online: https://beta.companieshouse.gov.uk/company/ 05573418/filing-history (accessed on 5 July 2019).

70. Typhoo. Slavery and Human Trafficking Statement. 2018. Available online: https://typhoo.co.uk/wp-content/ uploads/2015/12/Slavery-Human-Trafficking-Statement-2018-1.pdf (accessed on 5 July 2019).

71. Companies House. Bettys and Taylors Group Ltd. 2017. Available online: https://beta.companieshouse.gov. uk/company/00500829/filing-history (accessed on 14 July 2019).

72. Yorkshire Tea. 2017. Available online: https://explore.yorkshiretea.co.uk/ (accessed on 14 July 2019).

73. Marquis, C.; Toffel, M.W.; Zhou, Y. Scrutiny, norms, and selective disclosure: A global study of greenwashing. Organ. Sci. 2016, 27, 483-504. [CrossRef]

74. Ramasastry, A. Corporate social responsibility versus business and human Rights: Bridging the gap between responsibility and accountability. J. Hum. Rights 2015, 14, 237-259. [CrossRef]

75. Wettstein, F. CSR and the debate on business and human rights: Bridging the great divide. Bus. Ethics Q. 2012, 22, 739-770. [CrossRef]

76. Oxfam. Addressing the Human Cost of Assam Tea. 2019. Available online: https://oxfamilibrary.openrepository. com/bitstream/handle/10546/620876/bp-human-cost-assam-tea-101019-en.pdf (accessed on 13 August 2020).

77. Methven O'Brien, C.; Dhanarajan, S. The corporate responsibility to respect human rights: A status review. Account. Audit. Account. J. 2016, 29, 542-567. [CrossRef]

78. European Commission. Study on Due Diligence Requirements through the Supply Chain. 2020. Available online: https:/op.europa.eu/en/publication-detail/-/publication/8ba0a8fd-4c83-11ea-b8b7-01aa75ed71a1/ language-en (accessed on 16 July 2020).

79. French Parliament. Loi No 2017-399 du 27 Mars 2017 Relative au Devoir de Vigiliance des Sociétés Mères et des Entreprises Donneuses d'ordre; French Parliament: Palais, France, 2017.

(C) 2020 by the authors. Licensee MDPI, Basel, Switzerland. This article is an open access article distributed under the terms and conditions of the Creative Commons Attribution (CC BY) license (http://creativecommons.org/licenses/by/4.0/). 